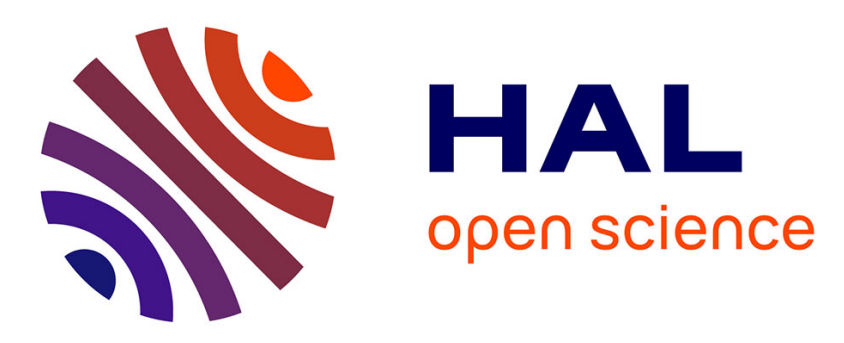

\title{
Cadmium detoxification processes in the digestive gland of cephalopods in relation to accumulated cadmium concentrations
}

Paco Bustamante, Richard P. Cosson, Isabelle Gallien, Florence Caurant, Pierre Miramand

\section{To cite this version:}

Paco Bustamante, Richard P. Cosson, Isabelle Gallien, Florence Caurant, Pierre Miramand. Cadmium detoxification processes in the digestive gland of cephalopods in relation to accumulated cadmium concentrations. Marine Environmental Research, 2002, 53 (3), pp.227-241. 10.1016/S01411136(01)00108-8 . hal-00186609

\section{HAL Id: hal-00186609 https://hal.science/hal-00186609}

Submitted on 9 Nov 2007

HAL is a multi-disciplinary open access archive for the deposit and dissemination of scientific research documents, whether they are published or not. The documents may come from teaching and research institutions in France or abroad, or from public or private research centers.
L'archive ouverte pluridisciplinaire HAL, est destinée au dépôt et à la diffusion de documents scientifiques de niveau recherche, publiés ou non, émanant des établissements d'enseignement et de recherche français ou étrangers, des laboratoires publics ou privés. 
Cadmium detoxification processes in the digestive gland of cephalopods in relation to accumulated cadmium concentrations

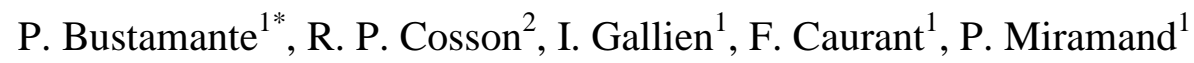

${ }^{1}$ Laboratoire de Biologie et d'Environnement Marins, UPRES-EA 3168, Université de La Rochelle, 22, Avenue Michel Crépeau, F-17042 LA ROCHELLE Cedex, France

2 ISOMer - UPRES-EA 2663, Laboratoire de Biologie Marine, Faculté des Sciences et Techniques, Université de Nantes, BP 92208, F-44322 NANTES, France

*Corresponding author: Dr. Paco Bustamante Laboratoire de Biologie et d'Environnement Marins, EA 3168 Université de La Rochelle Av. Michel Crépeau F-17042 La Rochelle (France)

Tel.: (+33) 546500294

Fax: (+33) 546458264

e-mail: pbustama@univ-lr.fr

\begin{abstract}
The high concentrations of cadmium recorded in the digestive gland of cephalopods from various temperate and subpolar waters suggest that these molluscs have developed efficient cadmium detoxification mechanisms. The subcellular distribution of cadmium in the digestive gland cells was investigated in seven cephalopod species from the Bay of Biscay (France) and the Faroe Islands. In most species, cadmium was mainly found in the cytosolic fraction of the digestive gland cells, reaching up to $86 \%$ of the total cadmium for the squid Loligo vulgaris from the Bay of Biscay. But species with the highest total level of cadmium showed a higher
\end{abstract}


percentage of cadmium associated to insoluble compounds. The quantification of metallothioneins (MTs) by the polarographic method was performed in order to evaluate the involvement of these proteins in the detoxification of the high amounts of bioaccumulated cadmium. Metallothionein levels in cephalopods ranged form $742 \pm 270$ to $3478 \pm 1572 \mu \mathrm{g} / \mathrm{g}$ wwt. No relationship could be established between total cadmium, cytosolic cadmium and MT levels suggesting the occurrence of other Cd-binding ligands. Although these proteins have not been characterised, as cadmium in the digestive gland of cephalopods is mainly associated with soluble ligands, a high potential transfer to predators can be predicted.

Keywords : cephalopods, cadmium, metallothionein, detoxification.

\section{INTRODUCTION}

Cephalopods are regarded as key species in many marine ecosystems (Amaratunga 1983, Rodhouse 1989). They represent an essential link in marine trophic chains and are eaten by many marine top predators, fish, birds and mammals (see the reviews of Clarke 1996, Croxall \& Prince 1996, Smale 1996, Klages 1996). Owing to their ecological importance, the few high background levels of cadmium reported in these molluscs (Martin \& Flegal 1975, Miramand \& Guary 1980, Smith et al. 1984, Finger \& Smith 1987, Miramand \& Bentley 1992, Bustamante 1998, Bustamante et al. 1998ab) are of particular interest. Moreover, species from subpolar areas showed higher levels of cadmium than those living in temperate ones (Bustamante 1998, Bustamante et al. 1998ab) while exposure to soluble metals in natural seawater is extremely low in polar regions (Mart et al. 1982, Donat \& Bruland 1995). In both areas, cadmium is mainly accumulated in the digestive gland (Miramand \& Guary 1980, Smith et al. 1984, Finger \& Smith 1987, Miramand \& Bentley 1992, Bustamante 1998, Bustamante et al. 1998a), reaching up to $98 \%$ of the total body cadmium in some species. 
Consequently, this organ appears to have a key function in the metabolism of cadmium in cephalopods. Very high levels of cadmium in the tissues of cephalopods would be expected to be toxic to the organisms unless efficient storage and detoxification mechanisms are available (Simkiss \& Taylor 1982, Phillips \& Rainbow 1989).

One well know detoxification strategy of marine invertebrates involves the binding of some trace metals to metallothioneins. These proteins which play a role in the homeostasis of the essential elements, copper and zinc (Engle \& Brouwer 1989, Cosson et al. 1991, George \& Olsson 1994), are induced by various metals (i.e. $\mathrm{Cd}, \mathrm{Cu}, \mathrm{Zn}, \mathrm{Ag}$ and $\mathrm{Hg}$ ). As a consequence, metallothioneins are considered to be involved in cadmium detoxification (Dallinger 1993, 1996, Roesijadi 1992, 1995, Viarengo \& Nott 1993). The occurrence of metallothioneins in cephalopods has not been demonstrated although the occurrence of proteins with a molecular weight similar to metallothioneins has been shown. These are associated mainly with copper, and, to lesser extent cadmium but little zinc (Tanaka et al. 1983, Finger \& Smith 1987).

Taking into account the very high levels of cadmium observed in several cephalopod species, the aim of our study was to investigate how they manage to tolerate such amounts of toxic metal. Our analyses provided us with information on the subcellular distribution of cadmium and with the involvement of metallothioneins in the detoxification processes. A comparison has been made between cephalopods from temperate and subpolar waters.

\section{MATERIALS \& METHODS}

The level of metallothionein (MTs) and the subcellular distribution of metals were determined in the digestive gland of several species of cephalopods collected by bottom trawl in waters of the Bay of Biscay and Faroe Islands during 1997. 


\section{Description of the samples}

Cephalopods were sampled 1) during a cruise on the Magnus Heinason in august 1997 on the Faroe eastern continental shelf, at several stations located between $60^{\circ} 30^{\prime}$ and $62^{\circ} 50^{\prime} \mathrm{N}$, and $3^{\circ} 40^{\prime}$ and $7^{\circ} 60^{\prime} \mathrm{W}$; 2) during the RESSGASC cruise in February and May 1997 on the continental shelf of the Bay of Biscay (French Atlantic coast), at several stations located between $45^{\circ} 14^{\prime}$ and $46^{\circ} 07^{\prime} \mathrm{N}$, and $01^{\circ} 24^{\prime}$ and $01^{\circ} 52^{\prime} \mathrm{W}$.

Only living animals were selected for on board-dissection (see below). We investigated both pelagic (i.e. squids) and benthic (i.e. cuttlefishes and octopuses) cephalopod species commonly encountered in French nearshore waters, i.e. Loliginidae and Ommastrephidae squids (Loligo vulgaris, Illex coindetii), cuttlefish (Sepia officinalis, S. elegans, S. orbignyana) and some other species from the Faroe Islands, i.e. the Ommastrephidae squid Todarodes sagittatus and the octopus Eledone cirrhosa. Table 1 gives the origin, number of individuals, mantle length and weight for each species of cephalopod.

\section{Preparation of the samples}

The digestive gland of each animal was isolated on board and deep-frozen in liquid nitrogen. In the laboratory, the samples were kept at $-80^{\circ} \mathrm{C}$ until used. Each sample was weighed (wet weight) and homogenised with a mortar and pestle on ice with 10 volumes of a $0.02 \mathrm{M}$ TRIS$\mathrm{HCl}$, $0.25 \mathrm{M}$ sucrose buffer (Tanaka et al., 1983), containing $1 \mathrm{mM}$ PMSF (phenylmethylsulfonylfluoride) as protease inhibitor and $5 \mathrm{mM}$ DTT (dithiothreitol) as reducing agent, at $\mathrm{pH} 8,6$. The homogenates were centrifuged at $100000 \mathrm{~g}$ for $1 \mathrm{~h}$ at $4^{\circ} \mathrm{C}$ in a Berkman LE-70 ultracentrifuge. Particle-free supernatants (cytosols) were separated from the pellet containing cellular membranes, nucleus, lysosomal and mitochondrial material. Two aliquots $(1 \mathrm{ml}$ each) were removed from the supernatant for protein and metallothionein quantification. Aliquots of the homogenates, cytosols and pellets were analysed for cadmium. 


\section{Cadmium analyses}

The content of cadmium in the different fractions was determined by atomic absorption spectrophotometry (AAS) after acid digestion with $4 \mathrm{ml}$ of $65 \% \mathrm{HNO}_{3}$ and $1 \mathrm{ml}$ of $70 \%$ $\mathrm{HClO}_{4}$ for 24 hours at $80^{\circ} \mathrm{C}$. The acid was removed from the samples by evaporation and the residues were diluted in $10 \mathrm{ml}$ of $1 \mathrm{~N}$ nitric acid. Cadmium was determined by flame and flameless AAS using a using a Varian spectrophotometer Vectra 250 Plus with deuterium background correction. Blanks and reference materials (dogfish liver DOLT-2, NRCC) were taken through the procedure in the same way as the sample. Our results $\left(21.2 \pm 1.5 \mu \mathrm{g} . \mathrm{g}^{-1} \mathrm{dwt}\right.$, $\mathrm{n}=3)$ were in good agreement with certified values $\left(20.8 \pm 0.5 \mu \mathrm{g} \cdot \mathrm{g}^{-1} \mathrm{dwt}\right)$. Levels of cadmium are given relative to the fresh weight of tissue.

\section{Quantification of metallothioneins}

The amounts of MTs were determined using the polarographic method (Olafson \& Sim 1979, Thompson \& Cosson 1984, Olafson \& Olsson 1991) in supernatants obtained after heat denaturation $\left(70^{\circ} \mathrm{C}, 15 \mathrm{~min}\right.$.) and centrifugation (15 000g, $10 \mathrm{~min}$.). The levels of MTs were expressed relative to the fresh weight of tissues using rabbit liver metallothionein (Sigma) for the standard addition calibration. All the reagents used did not give a polarographic signal during the dosage of metallothioneins (Erk \& Raspor 2000). 


\section{Gel-filtration chromatography}

Aliquots of heat-treated cytosol from the digestive gland of each species of cephalopods were chromatographed on a Waters Protein-Pack $125(7.8 \times 300 \mathrm{~mm})$ column and eluted with $0.1 \mathrm{M}$ TRIS-HCl, $0.25 \mathrm{M}$ sucrose buffer, $\mathrm{pH}$ 8.6. The column was maintained at $4^{\circ} \mathrm{C}$ and the samples were collected as $1.5 \mathrm{ml}$ fractions. The ultraviolet absorbency of the eluate was measured at $\lambda=254 \mathrm{~nm}$ and $\lambda=280 \mathrm{~nm}$. Differential pulse polarography was used to determine the thiolic content of each chromatographic fraction as explained above. The column was calibrated for molecular weight estimations with Bovine Serum Albumin (66 kDa), Rabbit Liver Metallothionein (12.5 kDa) and Aprotinine $(6.5 \mathrm{kDa})$ as standard markers.

\section{RESULTS}

\section{Subcellular distribution}

The partitioning of $\mathrm{Cd}$ between the pellet and the soluble fractions as a function of the total Cd content in the digestive gland is shown in Figure 1. A significant negative correlation exists between these parameters $(\mathrm{df}=6, \mathrm{r}=0.68, P<0.05)$. The distribution of cadmium between the pellet and the supernatant was fairly stable in each species. Two-way ANOVA did not show any significant differences among size and sex for the species with numerous individuals (i.e. Todarodes sagittatus and Loligo vulgaris) (Figure 2).

Partitioning of cadmium between the pellet and the supernatant was highly variable between species (Figure 1). Nevertheless, more than $50 \%$ of cadmium was present in the soluble fraction in most of the species, reaching up to $86 \pm 12 \%$ for the squid Loligo vulgaris from the Bay of Biscay; the only exception was the octopus Eledone cirrhosa from the Faroe Islands where only $42 \pm 17 \%$ of the total cadmium was found associated to the soluble fraction. 
Species with the lowest cadmium levels displayed the highest percentage of soluble cadmium (e.g. L. vulgaris).

The subcellular distributions of cadmium in the digestive gland of the squids Loligo vulgaris from the Bay of Biscay and Todarodes sagittatus from the Faroe Islands are shown in Figure 3. The amount of cadmium in the cytosolic fraction increased significantly as a function of total cadmium level in the digestive gland of both species $(\mathrm{df}=16, \mathrm{r}=0.991, P<0.001$ for $L$. vulgaris and $\mathrm{df}=20, \mathrm{r}=0.887, P<0.001$ for $T$. sagittatus) whilst the amount of cadmium in the insoluble fraction increased significantly with the total cadmium level in the digestive gland only for $T$. sagittatus $(\mathrm{df}=20, \mathrm{r}=0.906, P<0.001)$.

\section{Metallothioneins}

Typical chromatographic elution profiles of the absorbance $(\lambda=254,280 \mathrm{~nm})$ in heat treated cytosol from the digestive gland of cephalopods are shown in Figure 4. Except for the squid Loligo vulgaris, the principal cadmium-binding component has an apparent molecular weight of approximately $6.5 \mathrm{kDa}$, eluting between fractions 6-7. However, all the cephalopods chromatographic profiles displayed absorbency peak around $12.5 \mathrm{kDa}$ that corresponds to the metallothionein pool. Thus, $75 \%$ of the polarographic activity was detected in these fractions showing unequivocally that thiolic response in the heat-treated cytosol corresponds to metallothionein fractions. Sepia officinalis was the only exception with $44 \%$ of the polarographic activity at $12.5 \mathrm{kDa}$ and $40 \%$ for molecular weight around 3 to $4 \mathrm{kDa}$. For $L$. vulgaris, another peak at $254 \mathrm{~nm}$ was detected in the fraction 2, corresponding to proteins having a molecular weight around $80 \mathrm{kDa}$.

The levels of metallothioneins in the heat-stable soluble fraction of the digestive gland of cephalopods and the levels of total cadmium in this tissue are shown in Figure 5. 
Metallothionein levels were fairly stable within species but were highly variable between species exhibiting a significant decrease $(\mathrm{df}=6, \mathrm{r}=0.81, P<0.001)$ when the $\mathrm{Cd}$ concentrations increased in the digestive gland. The concentrations ranged from $700 \pm 300 \mu \mathrm{g} \cdot \mathrm{g}^{-1}$ wwt in the octopus Eledone cirrhosa from the Faroe Islands up to $3500 \pm 600 \mu \mathrm{g} . \mathrm{g}^{-1}$ wwt in the squid Loligo vulgaris from the Bay of Biscay and corresponded respectively to the highest and the lowest total cadmium levels in the digestive gland (i.e. $4 \pm 2 \mu \mathrm{g} \cdot \mathrm{g}^{-1}$ wwt and $397 \pm 126 \mu \mathrm{g} \cdot \mathrm{g}^{-1}$ wwt).

\section{DISCUSSION}

In our study, except in Eledone cirrhosa from the Faroe Islands, cadmium was mainly located in the soluble fraction of the digestive gland cells, probably bound to cytosolic proteins. Very few studies have investigated the subcellular distribution of trace elements in the digestive gland of cephalopods and results are quite different between authors (Rocca 1969, Decleir et al. 1978, Tanaka et al. 1983, Finger \& Smith 1987). Copper has been investigated in all these studies, but the subcellular distribution of cadmium has only been studied by Tanaka et al. (1983) and Finger \& Smith (1987). Tanaka et al. (1983) found that most of the cadmium was bound to the organelles of the digestive gland cells of the squid Todarodes pacificus, with only $26 \pm 3 \%$ of the metal in the cytosolic fraction. On the contrary, most of this metal, i.e. $70 \pm 10 \%$, was bound to cytosolic proteins in the squid Nototodarus gouldi (Finger \& Smith 1987). Despite very different subcellular distributions between T. pacificus and N. gouldi, total cadmium levels in the digestive gland were in the same range within both species, ranging from 40 to $100 \mu \mathrm{g} . \mathrm{g}^{-1} \mathrm{dwt}$ for T. pacificus and from 11 to $88 \mu \mathrm{g} \cdot \mathrm{g}^{-1} \mathrm{dwt}$ for $N$. gouldi (Tanaka et al. 1983, Finger \& Smith 1987). Our results concerning seven cephalopod species are in good agreement with those of Finger \& Smith (1987) but not with the results of Tanaka et al. (1983) (Figure 1). 
The subcellular distribution of cadmium seems to vary according to the levels of total cadmium in the tissue (Figure 1). Thus, comparing species, as total cadmium levels increase in the tissue, the metal is proportionately more abundant in the insoluble fraction, bound to organelles and/or membranes. Trace element precipitation into metal-rich granules is an efficient metal detoxification mechanisms reported for a great number of invertebrate species (Coombs \& George 1978, Brown 1982, Taylor \& Simkiss 1984). These granules function in the storage and excretion of essential and non-essential metals, and their production is common in all major phyla (Brown 1982, George 1982). Thus, the observed increase of total cadmium levels in the digestive gland of cephalopods, resulting in the storage of cadmium in an insoluble form rather than via binding to cytosolic proteins, could be considered as more efficient to counteract the toxicity of the metal. Ultrastructural observations failed to show such insoluble compounds in several cephalopod species (Mangold \& Bidder 1989). Similar observations were made in the digestive gland cells of the squid Todarodes sagittatus from the Faroe Islands, a species which exhibited relatively high cadmium levels (Bustamante 1998): thus, microanalytical investigations of the digestive gland cells of this Faroese squid did not show any cadmium accumulations likely to explain the high cadmium levels of the digestive gland (Bustamante 1998). The absence of granule-like structures has been noted for the digestive gland cells of the loliginid squids Loligo forbesi and L. vulgaris, and in the cuttlefish Sepia officinalis (Boucaud-Camou \& Boucher-Rodoni 1983, Boucher-Rodoni \& Boucaud-Camou 1987). Nevertheless, metal-rich spherules, mostly containing copper, have been described in S. officinalis (Martoja \& Marcaillou 1993). These authors suggested that the metals would be complexed by metallothioneins in these spherules. However, the presence of such structures remains controversial, as their existence has not been confirmed by other studies (Renata Boucher-Rodoni, pers. comm.). 
Among organelles, lysosomes would be expected to play an important role in cadmium detoxification as has been reported for bivalves (Moore 1990, Taylor 1995, Marigomez et al. 1995). In invertebrate organisms, lysosomes are known to accumulate both essential and toxic metals from the cytosol of the digestive gland cells. Lysosomes contain several hydrolytic enzymes and function as a digestive system in the cells. Finally, at their last stage of maturity, they accumulate cellular waste products which cannot be degraded (Dallinger 1993). It is therefore not surprising that metals are found in lysosomal residual bodies (Dallinger 1995). In cephalopods, the digestive gland is involved in digestive and absorptive functions (Boucaud-Camou 1974, Boucaud-Camou \& Yim 1980, Boucher-Rodoni \& Boucaud-Camou 1987). The lysosomal system is highly developed with several typical structures, i.e. heterolysosomes and heterophagosomes, "boules", residual bodies and brown bodies. Although microanalytical investigations have not shown any accumulation of cadmium (Bustamante 1998), such lysosomal structures are probably involved in the compartmentalisation of metals in the digestive gland cells of cephalopods as has been reported for other mollusc species (Coombs \& George 1978, George \& Viarengo 1985, Viarengo \& Nott 1993, Marigomez et al. 1995). Moreover, lysosomes can contain degradation products of metallothionein indicating that they may serve as a final storage site of degraded metallothioneins and possibly, of other metal-binding proteins (Dallinger 1995).

Cadmium sequestration seems to depend on levels of Cd contamination in the digestive gland. While the cytosolic content of cadmium increased significantly as a function of cadmium levels in the tissue in both Loligo vulgaris from the Bay of Biscay and Todarodes sagittatus from the Faroe Islands (Figure 3), the accumulation in the insoluble fraction was correlated with cadmium levels only for the Faroese squids. This difference in cadmium partitioning could be explained by the following hypothesis. When a threshold level, located between the highest Loligo vulgaris and the lowest Todarodes sagittatus total cadmium level 
in the digestive gland (i.e. 8 and $12 \mu \mathrm{g} . \mathrm{g}^{-1}$ wwt, respectively) is reached, the detoxification processes are modified and the storage of cadmium in organelles starts. Cd-binding proteins would be efficient enough to detoxify cadmium in loliginid squids from the Bay of Biscay while in ommastrephid ones, this system would be overloaded and lead to an alternative process assuring an efficient detoxification of cadmium. On an ultrastructural point of view, the digestive gland cells of loliginid squids are different from those of other cephalopods. They do not have the "boules" structures characteristic of most cephalopod species (BoucherRodoni \& Boucaud-Camou 1987). In the cuttlefish Sepia officinalis, some of these "boules" are considered as heterolysosomes and heterophagosomes involved in intracellular digestion (Boucaud-Camou 1976, Boucaud-Camou \& Yim 1980). Although brown bodies which contain residues of the digestion, account for the digestion ability of endogenous or exogenous compounds by loliginid digestive cells, the lack of "boules" in these cells might mean that particle capture and intracellular digestion do not occur widely in their digestive glands (Boucher-Rodoni \& Boucaud-Camou 1987). Generally, in the Loliginidae family, the lysosomal system is less developed than in other cephalopod species. Consequently, loliginid squids could be physiologically limited to detoxify cadmium via binding to insoluble compounds. Alternatively, these squids could have developed mechanisms favouring the excretion of cadmium.

The occurrence of metallothioneins was suspected when considering the chromatograms of metalloproteins from the digestive gland of the squids Nototodarus gouldi, Todarodes pacificus and Ommastrephes bartrami, eluting between $10 \mathrm{kDa}$ and $18 \mathrm{kDa}$ (Tanaka et al. 1983, Finger \& Smith 1987, Castillo \& Maita 1991). Since then, our investigations are among the first to attempt to determine the importance of these proteins in the detoxification processes of cadmium in cephalopods. 
The quantification of metallothioneins showed up high specific differences, with the highest metallothionein levels corresponding to the lowest total cadmium levels in the digestive gland (i.e. Loligo vulgaris from the Bay of Biscay) and on the contrary, the lowest levels of metallothioneins corresponding to the highest total cadmium levels (i.e. Eledone cirrhosa from the Faroe Islands) (Figure 5). These observations are in accordance with the variation of the percentage of soluble cadmium (see above).

Metallothionein levels measured in cephalopods from this study (i.e from $0.7 \pm 0.3$ to $3.5 \pm$ $0.6 \mathrm{mg} \cdot \mathrm{g}^{-1} \mathrm{wwt}$ ) were of the same order of magnitude than those reported for other mollusc species. Thus, in the digestive gland of the mussel Mytilus galloprovincialis and the gastropod Littorina littorea, reported levels range from 0.6 to $2.1 \mathrm{mg} \cdot \mathrm{g}^{-1}$ wwt (Pavicic et al. 1993, Bebianno et al. 1992). Cadmium levels in cephalopod digestive glands however were one or two orders of magnitude higher than those of these molluscs. Cadmium is largely considered as an inducer of the synthesis of metallothioneins in several phyla, and owing to the high cadmium levels in cephalopods, high metallothionein levels could be expected. It was not the case. On the contrary, considering the different cephalopod species in our study, metallothionein levels were negatively correlated with total cadmium levels in the digestive gland (Figure 5). In this mollusc class, metallothioneins do not represent the major response to the accumulation of cadmium in the tissue and cannot be considered as a biomarker of exposure to this metal. Cadmium detoxification could occur with other metalloproteins than metallothioneins. This hypothesis is strengthened by results found by other authors working on cephalopods. Tanaka et al. (1983) and Castillo et al. (1990) have shown that most of the cytosolic cadmium in the digestive gland of the squids Todarodes pacificus and Onychoteuthis borealojaponica was bound to proteins weighing more than $70 \mathrm{kDa}$. Only a small part of the soluble cadmium was bound to low molecular weight proteins $(<3 \mathrm{kDa})$ or to proteins of size similar to metallothionein $(10 \mathrm{kDa}$ to $16 \mathrm{kDa})$. Moreover, Finger \& Smith 
(1987) have reported the occurrence of Cd-binding proteins with a high molecular weight (> to $70 \mathrm{kDa}$ ) in the digestive gland of the squid Nototodarus gouldi.

\section{CONCLUSIONS}

The high levels of cadmium reported for cephalopod species from different areas of the world suggest that these organisms have developed efficient detoxification mechanisms. The subcellular distribution of cadmium in the digestive gland between cytosol and organelles suggests that the major part of this metal is associated with cytosolic proteins, except in Eledone cirrhosa from the Faroe Islands. The quantification of metallothioneins suggests a limited participation of these proteins in the detoxification of cadmium in cephalopods. An alternative mode of sequestration (lysosomal) could be activated when the level of cadmium in the digestive gland reaches a threshold value. Thus, further studies are needed to characterise the proteins involved in cadmium detoxification in cephalopods.

Cephalopods are considered to be a vector for the transfer of cadmium to top marine predators (Honda and Tatsukawa 1983, Muirhead and Furness 1988, Bustamante et al. 1998b). This is strengthened by our results which have demonstrated the subcellular localisation of cadmium

(Table 2). Recent investigations using radiollabelled food with ${ }^{109} \mathrm{Cd}$ have showed that ${ }^{109} \mathrm{Cd}$ bound to cytosolic proteins was transferred with a high efficiency and ${ }^{109} \mathrm{Cd}$ bound to insoluble compounds was relatively unavailable (Wallace \& Lopez 1997). Thus, the high bioavailability of cadmium in the digestive gland cells indicates a high potential for the trophic transfer of the metal to their predators such as marine mammals and seabirds. 


\section{ACKNOWLEDGEMENTS}

We thanks the captains and the crews of Magnus Heinason and Gwen-Drez RVs for their kind co-operation as well as the participating scientists, especially Rogvi Mouritsen on Magnus Heinason and Jacques Labastie on Gwen-Drez. This work was supported financially by the "Conseil Régional Poitou-Charentes" and Rhodia (Rhône-Poulenc).

\section{REFERENCES}

Amaratunga, T. (1983). The role of cephalopods in the marine ecosystem. In I.F. Caddy, Advances in assessment of world cephalopod resources. FAO Fish Tech Pap, 231, 379-415.

Bebianno, M.J., Langston, W.J., \& Simkiss, K., (1992). Metallothionein induction in Littorina littorea (Mollusca: Prosobranchia) on exposure to cadmium. Journal of Marine Biology of Association of the United Kingdom, 72, 329-342.

Boucaud-Camou, E. (1974). Localisation d'activités enzymatiques impliquées dans la digestion chez Sepia officinalis L. Archives de Zoologie expérimentale et générale, 115, 5-27.

Boucaud-Camou, E. (1976). Structure et fonction de la glande digestive ("foie") de la Seiche, Sepia officinalis L. (Mollusque, Céphalopode). Bulletin de la Société Zoologique de France, 101,887 .

Boucaud-Camou, E., \& Yim, M. (1980). Fine structure and function of the digestive cell of Sepia officinalis (Mollusca : Cephalopoda). Journal of Zoology London, 191, 89-105. 
Boucaud-Camou, E., \& Boucher-Rodoni, R. (1983). Feeding and digestion in Cephalopods. In A.S.M. Saleuddin \& K.M. Wilbur, The Mollusca, Vol. 5. Physiology, Part 2. (pp 149-187). New York and London: Academic Press.

Boucher-Rodoni, R., \& Boucaud-Camou, E. (1987). Fine structure and absorption of ferritin in the digestive organs of Loligo vulgaris and L. forbesi (Cephalopoda, Teuthoidea). Journal of Morphology, 193, 173-184.

Brown, B.E. (1982). The form and function of metal-containing 'granules' in invertebrate tissues. Biol Rev Cam Philos Soc, 57, 621-667.

Bustamante, P. (1998) Etude des processus de bioaccumulation et de détoxication d'éléments traces (métaux lourds et terres rares) chez les mollusques céphalopodes et bivalves pectinidés. Implication de leur biodisponibilité pour le transfert vers les prédateurs. Thesis, University of La Rochelle, 290 p.

Bustamante, P., Cherel, Y., Caurant, F., \& Miramand, P. (1998a). Cadmium, copper and zinc in octopuses from Kerguelen Islands, Southern Indian Ocean. Polar Biology, 19, 264-271.

Bustamante, P., Caurant, F., Fowler, S.W., \& Miramand, P. (1998b). Cephalopods as a vector for the transfer of cadmium to top marine predators in the north-east Atlantic Ocean. The Science of the Total Environment, 220, 71-80. 
Castillo, L.V., Kawaguchi S., \& Maita Y. (1990). Evidence for the presence of heavy metal binding proteins in the squid, Onychoteuthis borealijaponica. In R. Hirano \& I. Hanyu, The Second Asian Fisheries Forum (991 p.). Manila: Asian Fish. Soc.

Castillo, L.V., \& Maita Y. (1991). Isolation and partial characterisation of cadmium binding proteins from the oceanic squid, Ommastrephes bartrami. Bull. Fac. Fish. Hokkaido Univ. 42(1), 26-34.

Clarke, M.R. (1996). Cephalopods as prey. III. Cetaceans. Philosophical Transactions of the Royal Society London Series B 351, 1053-1065.

Coombs, T.L., \& George, S.G. (1978). Mechanisms of immobilisation and detoxification of metals in marine organisms. In D.S. McLusky \& A.J. Berry, Physiology and behaviour of marine organisms. Proceeding off the 12th European Symposium on Marine Biology (pp 179187). Oxford: Stirling, Pergammon Press.

Cosson, R.P., Amiard-Triquet, C., \& Amiard, J.C. (1991). Metallothioneins and detoxification. Is the use of detoxification proteins for MTs a language abuse ? Water Air and Soil Pollution, 57/58, 555-567.

Croxall, J.P., \& Prince, P.A. (1996). Cephalopods as prey. I. Seabirds. Philosophical Transactions of the Royal Society London Series B, 351, 1023-1043.

Dallinger, R. (1993). Strategies of metal detoxification in terrestrial invertebrates: Synopsis and perspectives. Comparative Biochemistry and Physiology, 113C, 125-133. 
Dallinger, R. (1995). Mechanisms of metal incorporation into cells. In M.P. Cajaraville, Cell biology in environmental toxicology (pp 135-154). Bilbo: University of the Basque Country Press Service.

Decleir, W., Vlaeminck, A., Geladi, P. \& Van Grieken, R. (1978). Determination of proteinbound copper and zinc in some organs of the cuttlefish Sepia officinalis L. Comparative Biochemistry and Physiology, 60B, 347-350.

Donat, J.R., \& Bruland, K.W. (1995). Trace elements in the oceans. In B. Salbu, \& E. Steinnes, Trace Elements in Natural Waters (pp 247-281). Boca Raton: CRC Press Inc.

Engle, D.W., \& Brouwer, M. (1989). Metallothionein and metallothionein-like proteins: physiological importance. Advances in Comparative Environmental Physiology, 5, 54-75.

Erk, M., \& Raspor, B. (2000) Advantages and disadvantages of voltametric method in studying cadmium-metallothionein interactions. Cellular and Molecular Biology,46(2), 269281.

Finger, J.M., \& Smith, J.D. (1987). Molecular association of $\mathrm{Cu}, \mathrm{Zn}, \mathrm{Cd}$ and ${ }^{210} \mathrm{Po}$ in the digestive gland of the squid Nototodarus gouldi. Marine Biology, 95, 87-91.

George, S.G. (1982) Subcellular accumulation and detoxification of metals in aquatic animals. In W.B. Vernberg, A. Calabresa, F.P. Thurnberg, \& F.J. Vernberg, Physiological mechanisms of marine pollutant toxicity (pp 3-55). New York : Academic Press. 
George, S.G., \& Viarengo, A. (1985). A model for heavy metal homeostasis and detoxification in mussels. In F.J. Thunrberg, E. Calabrese, \& W.B. Vernberg, Marine Pollution and Physiology : recent advances (pp 125-143). Columbia: U. South Carolina Press.

George, S.G., \& Olsson, P.E. (1994). Metallothioneins as indicators of trace metal pollution. In K. J. M. Kramer, Biomonitoring of Coastal Waters Estuaries (pp 151-171). Boca Raton: RC Press Inc.

Honda, K., \& Tatsukawa, R. (1983). Distribution of cadmium and zinc in tissues and organs, and their age-related changes in striped dolphin, Stenella coeruleoalba. Archives of Environmental Contamination and Toxicology, 12, 543-550.

Klages, N. T. W. (1996). Cephalopods as prey. II. Seals. Philosophical Transactions of the Royal Society London Series, 351, 1045-1052.

Mangold, K., \& Bidder, A.M. (1989). L'appareil digestif et la digestion. In K. Mangold, Céphalopodes. In P.P. Grassé, Traité de Zoologie Tome V (pp 321-373). Paris: Masson.

Marigomez, I., Soto, M., \& Cajaraville, M.P. (1995). Morphological patterns of cell and tissue systems involved in metal handling and metabolism. In M.P. Cajaraville, Cell Biology in Environmental Toxicology (pp 89-134). Bilbo: University of the Basque Country Press Service. 
Mart, L., Rützel, H., Klahre, P., Sipos, L., Platzek, U., Valenta, P., \& Nürnberg, H.W. (1982). Comparative studies on the distribution of heavy metals in the oceans and coastal waters. The Science of the Total Environment, 26, 1-17.

Martin, J.H., \& Flegal, A.R. (1975). High copper concentrations in squid livers in association with elevated levels of silver, cadmium, and zinc. Marine Biology, 30, 51-55.

Martoja, M., \& Marcaillou, C. (1993). Localisation cytologique du cuivre et de quelques autres métaux dans la glande digestive de la seiche, Sepia officinalis L. (Mollusque Céphalopode). Canadian Journal of Fisheries and Aquatic Sciences, 50(3), 542-550.

Miramand, P., \& Bentley, D. (1992). Concentration and distribution of heavy metals in tissues of two cephalopods, Eledone cirrhosa and Sepia officinalis, from the French coast of the English Channel. Marine Biology, 114, 407-414.

Miramand, P., \& Guary, J.C. (1980). High concentrations of some heavy metals in tissues of the Mediterranean octopus. Bulletin of Environmental Contamination and Toxicology, 24, 783-788.

Moore, M.N. (1990). Lysosomal cytochemistry in marine environmental monitoring. Histochemistry Journal, 22, 187-191.

Muirhead, S.J., \& Furness, R.W. (1988). Heavy metal concentrations in the tissues of seabirds from Gough Island, South Atlantic Ocean. Marine Pollution Bulletin, 19, 278-283. 
Olafson, R.W., \& Sim, R.G. (1979). An electrochemical approach to quantification and characterisation of metallothioneins. Analytical Biochemistry, 100, 343-351.

Olafson, R.W., \& Olsson, P.E. (1991). Electrochemical detection of metallothionein. Methods in Enzymology, 205, 205-213.

Pavicic, J., Raspor, B., \& Martincic, D. (1993). Quantitative determination of metallothionein-like proteins in mussels. Methodological approach and field evaluation. Marine Biology 115, 435-444.

Phillips, D.J.H., \& Rainbow, P.S. (1989). Strategies of metal sequestration in aquatic organisms. Marine Environmental Research, 28, 207-210.

Rocca, E. (1969). Copper distribution in Octopus vulgaris Lam. hepatopancreas Comparative Biochemistry and Physiology, 28, 67-82.

Roesijadi, G. (1992). Metallothionein in metal regulation and toxicity in aquatic animals. Aquatic Toxicology, 22, 81-114.

Roesijadi, G. (1996). Metallothionein and its role in toxic metal regulation. Comparative Biochemistry and Physiology, 113C, 117-123.

Rodhouse, P.G. (1989). Antarctic cephalopods - a living marine resource ? Ambio, 18(1), 5659. 
Simkiss, K., \& Taylor, M.G. (1982). Metal detoxification and bioaccumulation in molluscs. Marine Biological Letters, 3, 187-201.

Smale, M.J. (1996). Cephalopods as prey. IV. Fishes. Philosophical Transactions of the Royal Society London Series B, 351, 1067-1081.

Smith, J.D., Plues, L., Heyraud, M., \& Cherry, R.D. (1984). Concentrations of the elements $\mathrm{Ag}, \mathrm{Al}, \mathrm{Ca}, \mathrm{Cd}, \mathrm{Cu}, \mathrm{Fe}, \mathrm{Mg}, \mathrm{Pb}$ and $\mathrm{Zn}$, and the radionuclides ${ }^{210} \mathrm{~Pb}$ and ${ }^{210} \mathrm{Po}$ in the digestive gland of the squid Nototodarus gouldi. Marine Environmental Research, 13, 55-68.

Tanaka, T., Hayashi, Y., \& Ishizawa, M. (1983). Subcellular distribution and binding of heavy metals in the untreated liver of the squid ; comparison with data from the livers of cadmium and silver exposed rats. Experientia, 39, 746-748.

Taylor, M.G. (1995). Mechanisms of metal immobilisation and transport in cells. In MP Cajaraville, Cell biology in environmental toxicology, (pp 155-169). Bilbo: University of the Basque Country Press Service.

Taylor, M.G., \& Simkiss, K. (1984). Inorganic deposits in invertebrates tissues. Environmental Chemistry, 3, 102-138.

Thompson, J.A.J., \& Cosson, R.P. (1984). An improved electrochemical method for the quantification of metallothioneins in marine organisms. Marine Environmental Research, 11, $137-152$. 
Viarengo, A., \& Nott, J.A. (1993). Mini-review. Mechanisms of heavy metal cation homeostasis in marine invertebrates. Comparative Biochemistry and Physiology, 104C, 355372.

Wallace, W.G., \& Lopez, G.R. (1997). Bioavailability of biologically sequestered cadmium and the implications of metal detoxification. Marine Ecology Progress Series, 147, 149-157. 
Table 1. Characteristics of the cephalopod samples.

\begin{tabular}{|c|c|c|c|c|c|}
\hline $\begin{array}{l}\text { Family } \\
\text { Species }\end{array}$ & $\begin{array}{c}\text { Number } \\
\text { of } \\
\text { individuals }\end{array}$ & Sex & $\begin{array}{l}\text { Mantle length } \\
(\mathrm{mm})\end{array}$ & $\begin{array}{l}\text { Weight } \\
(\mathrm{g})\end{array}$ & Origin \\
\hline \multicolumn{6}{|l|}{ Sepiidae } \\
\hline Sepia elegans & 5 & $5 \mathrm{E}$ & $63 \pm 6$ & $33 \pm 11$ & Bay of Biscay \\
\hline S. officinalis & 8 & $2 \Gamma, 6 \mathrm{E}$ & $153 \pm 63$ & $507 \pm 522$ & $"$ \\
\hline S. orbignyana & 7 & $3 \Gamma, 4 \mathrm{E}$ & $84 \pm 20$ & $153 \pm 53$ & $"$ \\
\hline \multicolumn{6}{|l|}{ Loliginidae } \\
\hline Loligo vulgaris & 27 & $15 \Gamma, 12 \mathrm{E}$ & $233 \pm 88$ & $434 \pm 302$ & Bay of Biscay \\
\hline \multicolumn{6}{|l|}{ Ommastrephidae } \\
\hline Illex coindetii & 9 & $5 \Gamma, 4 \mathrm{E}$ & $206 \pm 43$ & $368 \pm 109$ & Bay of Biscay \\
\hline Todarodes sagittatus & 21 & $11 \Gamma, 10 \mathrm{E}$ & $228 \pm 43$ & $199 \pm 46$ & Faroe Islands \\
\hline \multicolumn{6}{|l|}{ Octopodidae } \\
\hline Eledone cirrhosa & 4 & $4 \Gamma$ & $101 \pm 8$ & $448 \pm 85$ & Faroe Islands \\
\hline
\end{tabular}

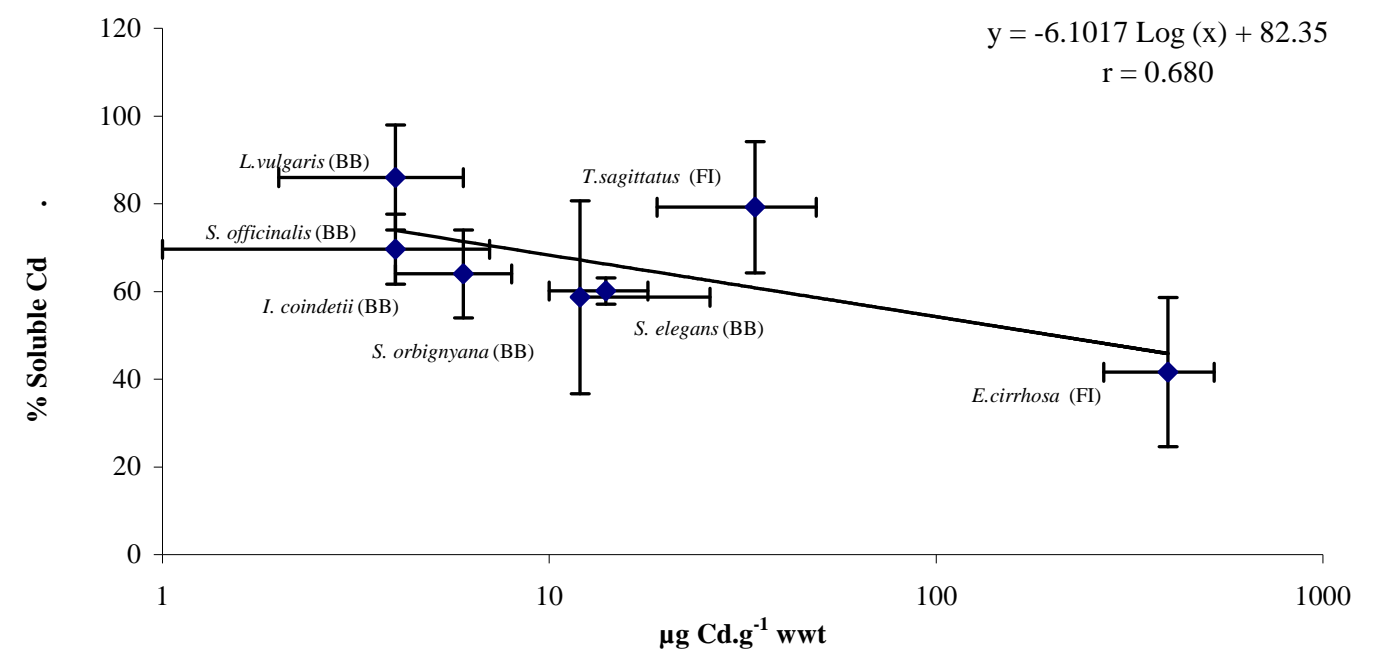

Figure 1. Partitioning of cadmium (as \% of soluble $\mathrm{Cd}$ ) in the digestive gland of cephalopods as a function of total cadmium levels in this organ (expressed as $\mu \mathrm{g} \mathrm{Cd.g^{-1 } w w t ) . ~ S c a l e ~ b a r s ~}$ represent 1 standard deviation. BB : Bay of Biscay; FI: Faroe Islands. 
Loligo vulgaris

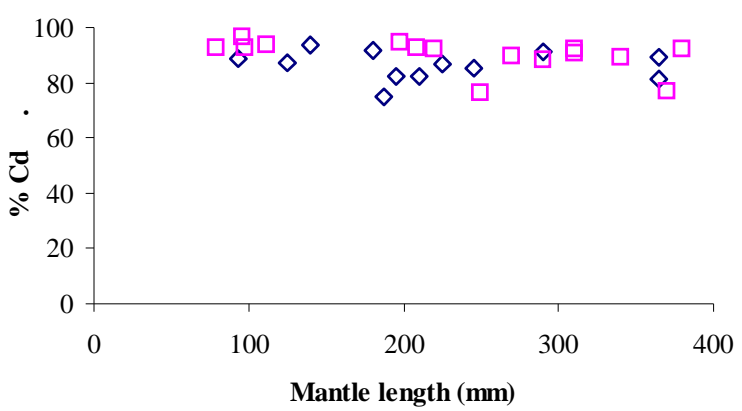

Todarodes sagittatus

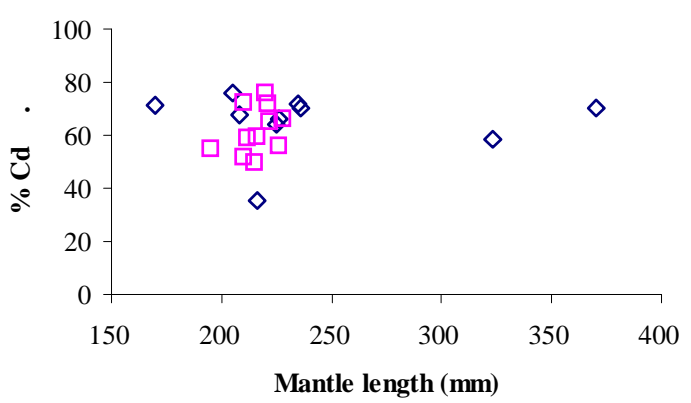

Figure 2. Partitioning of cadmium in the cytosolic fraction (\% of soluble Cd) of the digestive gland of 2 squid species, Todarodes sagittatus from Faroe Islands and Loligo vulgaris from the Bay of Biscay as a function of mantle length for males $(\square)$ and females $(\diamond)$.
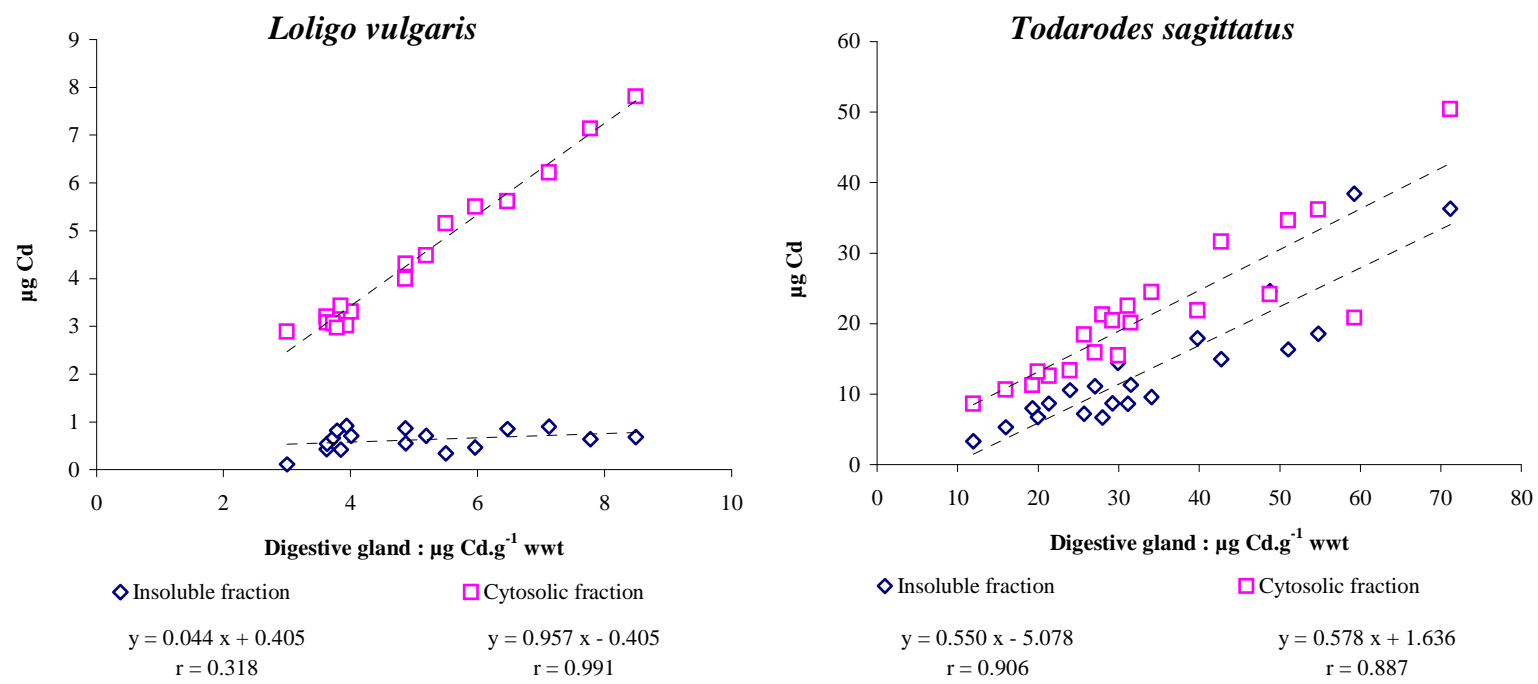

Figure 3. Quantity of cadmium (as $\mu \mathrm{g}$ ) in the soluble and insoluble fractions of the digestive gland of the squids Loligo vulgaris from the Bay of Biscay and Todarodes sagittatus from the Faroe Islands as a function of total cadmium level $\left(\mu \mathrm{g} \mathrm{Cd.} \mathrm{g}^{-1} \mathrm{wwt}\right)$ in this tissue. 
Table 2. Percentage of $\mathrm{Cd}, \mathrm{Cu}$ and $\mathrm{Zn}$ in the soluble fraction of the cytosol from different cephalopod species.

\begin{tabular}{|c|c|c|c|c|c|}
\hline \multirow{2}{*}{$\begin{array}{l}\text { Family } \\
\text { Species }\end{array}$} & \multirow{2}{*}{$\begin{array}{c}\text { Number } \\
\text { of } \\
\text { individuals }\end{array}$} & \multicolumn{3}{|c|}{ Metal percentage in the soluble fraction } & \multirow[t]{2}{*}{ Origin } \\
\hline & & $\mathrm{Cd}$ & $\mathrm{Cu}$ & $\mathrm{Zn}$ & \\
\hline \multicolumn{6}{|l|}{ Sepiidae } \\
\hline Sepia elegans & 5 & $59 \pm 22$ & $72 \pm 17$ & $60 \pm 15$ & Bay of Biscay \\
\hline S. officinalis & 8 & $64 \pm 8$ & $69 \pm 9$ & $60 \pm 9$ & $"$ \\
\hline S. orbignyana & 7 & $70 \pm 8$ & $69 \pm 6$ & $72 \pm 10$ & $"$ \\
\hline \multicolumn{6}{|l|}{ Loliginidae } \\
\hline Loligo vulgaris & 27 & $86 \pm 12$ & $86 \pm 15$ & $82 \pm 6$ & Bay of Biscay \\
\hline \multicolumn{6}{|l|}{ Ommastrephidae } \\
\hline Illex coindetii & 9 & $79 \pm 15$ & $84 \pm 12$ & $79 \pm 17$ & Bay of Biscay \\
\hline Todarodes sagittatus & 21 & $64 \pm 10$ & $70 \pm 8$ & $61 \pm 9$ & Faroe Islands \\
\hline \multicolumn{6}{|l|}{ Octopodidae } \\
\hline Eledone cirrhosa & 4 & $42 \pm 17$ & $53 \pm 14$ & $50 \pm 3$ & Faroe Islands \\
\hline
\end{tabular}

Loligo vulgaris

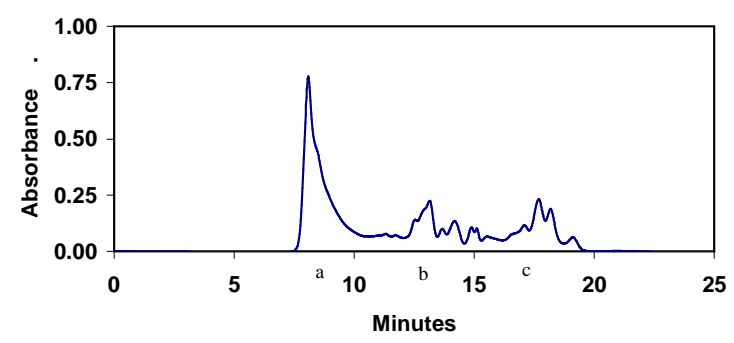

Eledone cirrhosa

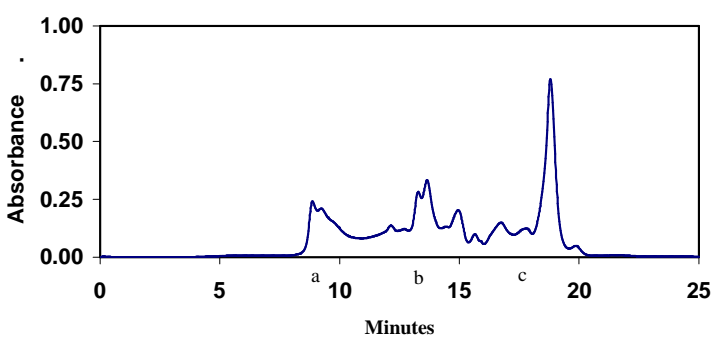

Sepia elegans

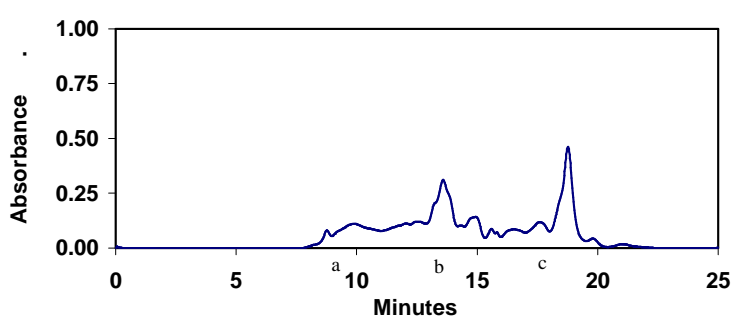

Sepia officinalis

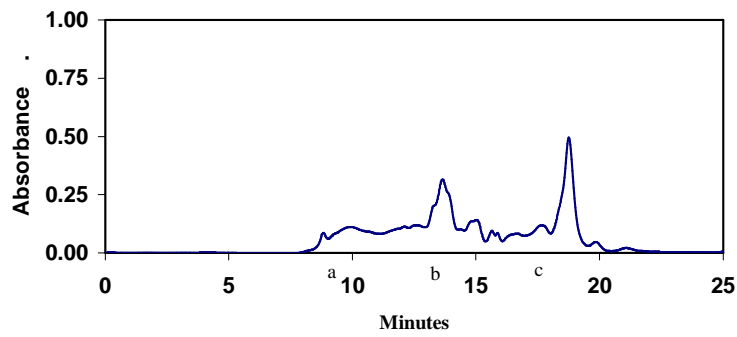

Figure 4. Chromatographic profiles of heat-denatured homogenates from the digestive gland of cephalopods : Waters Protein-Pack 125 (7.8 x 300 mm) column; 100mM Tris-HCl, pH 8.6; $\lambda=254 \mathrm{~nm}$; a : Bovine Serum Albumine (66 kDa), b : Rabbit Liver Metallothionein (12.5 $\mathrm{kDa}), \mathrm{c}:$ Aprotinine $(6.5 \mathrm{kDa})$ 


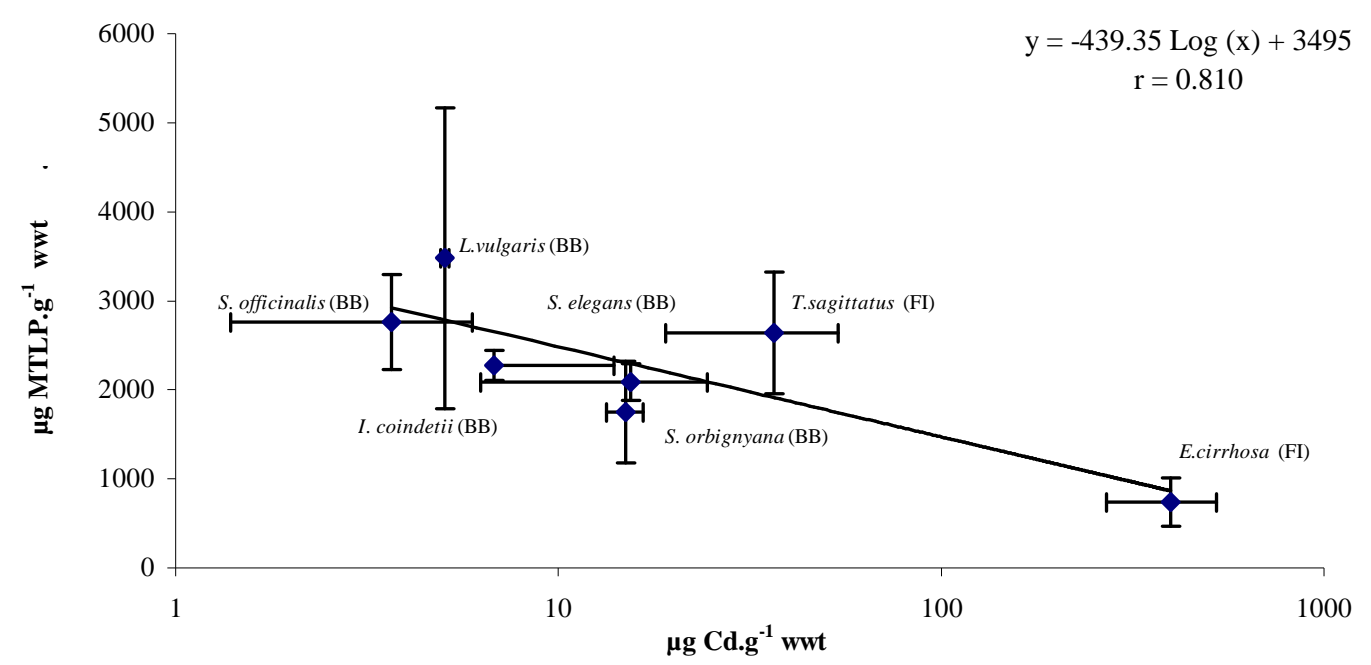

Figure 5. Metallothionein-like protein levels in the heat-stable soluble fraction of the digestive gland of several cephalopod species as a function of the level of total cadmium in this tissue. Each point represents the mean \pm 1 standard deviation for a single species. BB : Bay of Biscay; FI: Faroe Islands. 